\title{
Why farm the city? Theorizing urban agriculture through a lens of metabolic rift
}

\author{
Nathan McClintock \\ Department of Geography, University of California, 507 McCone Hall, \#4740, Berkeley, \\ CA94720,USA, mcclintock@berkeley.edu
}

Received on July 15, 2009; accepted on December 14, 2009

\begin{abstract}
Urban agriculture (UA) is spreading across vacant and marginal land worldwide, embraced by government and civil society as source of food, ecosystems services and jobs, particularly in times of economic crisis. 'Metabolic rift' is an effective framework for differentiating UA's multiple origins and functions across the Global North and South. I examine how UA arises from three interrelated dimensions of metabolic rift-ecological, social and individual. By rescaling production, reclaiming vacant land and 'de-alienating' urban dwellers from their food, UA also attempts to overcome these forms of rift. Considering all three dimensions is valuable both for theory and practice.
\end{abstract}

Keywords: alienation, commodification, the commons, metabolism, scale, urban farming

JEL Classifications: Q, R

\section{Introduction}

Part of the momentum surrounding food system relocalization, urban agriculture (UA) is sprouting up in the empty spaces of post-industrial landscapes throughout the industrialized world — in vacant lots, road medians, parks - reminiscent of the patchwork of vegetable gardens and livestock enclosures that are a part of the urban streetscape in much of the Global South. The spike in oil and food prices in late 2007 and early 2008 and the shocks of the current economic meltdown have led to a tightening of belts and a growing interest in UA as a way to lower food costs. Sales of vegetable seeds since the meltdown have increased 20 per cent and news stories about UA pepper the media at a frenzied pace. In Washington, First Lady Michelle Obama and a handful of fifth-graders from a nearby ele- mentary school plant a vegetable garden, the first of its kind at the White House in 60 years. The Vancouver city council legalizes chicken ownership within the city limits. 'Guerrilla gardeners' in London plant a vegetable patch on a roundabout. In Detroit, goats and chickens graze some of the 60 square miles of vacant lots left fallow by capital's flight from the city.

The renewed interest in UA should come as no surprise. Historically, urban food production in the US and Britain has flourished in such moments of economic crisis. As we find ourselves once again in the throes of a crisis of capitalism, the popularity of UA in the Global North has surged and the discourse surrounding it has shifted from one of recreation and leisure to one of urban sustainability and economic resilience. Even the terms used to 
describe it have shifted in the Global North; 'urban agriculture' is replacing 'community gardening' in everyday parlance, placing it (despite its much smaller scale) in the same category as UA in the Global South, where livestock and small plots of food crops have persisted as part of the urban landscape.

While the motivations and functions of UA vary greatly across the globe, the widespread discourse surrounding UA in the North does little to differentiate it from its Southern counterpart. Over the last decade or so, as concern over the ecological impacts of urbanization adopts an increasingly Malthusian timbre, government agencies, non-governmental organizations and farmers' groups have touted the potential for UA to help buffer incomes and food security in the rapidly urbanizing South (Mougeot, 2005; UNDP, 1996; van Veenhuizen, 2006). They extol the virtues of UA's multifunctionality: it improves food security and creates jobs, serves as a sink for urban waste and cools cities. The distance between production and consumption-so-called 'food miles'-decreases, lowering fossil fuel use and transportation costs. In the North, advocates echo this discourse, also adding UA's ability to strengthen a sense of community, reconnect consumers with farmers, raise awareness of environmental and human health and keep money circulating locally. Ecological farming practices reduce the amount of agri-chemicals used, curbing environmental pollution and threats to public health. In short, advocates argue that UA creates a more ecologically sound, resilient and productive landscape (UNDP, 1996; Viljoen, 2005).

An undifferentiated view of UA and its possibilities, however, may result in its prescription as a panacea for urban ills without consideration for the geographic particularities of a particular city. Can we generalize about why people farm in the city? And more importantly, can we make broad claims about why people should farm urban spaces? To better understand the dynamics giving rise to UA in various settings in both the North and South, as well as the ways in which UA has developed as a multifunctional response to these dynamics, a theoretical framework bridging political economy, urban geography, agroecology and public health would be helpful not only for agri-food scholars but also for practitioners wishing to engage with UA.

The theory of metabolic rift offers one such lens. Over the last decade, environmental sociologists and geographers have elaborated Marx's argument that the development of capitalism (and the urbanization that followed) alienated humans from the natural environment and disrupted our traditional forms of 'social metabolism', the material transformation of the biophysical environment for the purpose of social reproduction (Clark and York, 2008; Foster, 1999, 2000; Moore, 2000; Swyngedouw, 2006). ${ }^{1}$ For Marx, labour was the key to understanding this relationship: "Labour is, first of all, a process between man and nature, a process by which man, through his own actions, mediates, regulates and controls the metabolism between himself and nature'" (Marx, 1976, 283). Understanding the linkages between mid-19th century environmental crises (such as declining agricultural soil fertility and rising levels of urban pollution) and the squalor of the worker therefore necessitated an understanding of the processes that disrupted (or created a 'rift') in pre-capitalist forms of social metabolism. Marx ascribed this rift to the expansion of capitalist modes of production (the rise of wage labour, in particular) and to urbanization arising from industrialization and the displacement of small-scale agriculture:

Large landed property reduces the agricultural population to an ever decreasing minimum and confronts it with an ever growing industrial population crammed together in large towns; in this way it produces conditions that provoke an irreparable rift in the interdependent process of social metabolism, a metabolism prescribed by the natural laws of life itself. The result of this is a squandering of the vitality of the soil, which is carried by trade far beyond the bounds of a single country. (Marx, 1981, 949)

As he explains, this process also cleaves a biophysical rift in natural systems (such as nutrient cycles), 
leading to resource degradation at points of production and pollution at points of consumption. Finally, this rift reifies a false dichotomy between city and country, urban and rural, humans and nature, obscuring and effacing the linkages between them.

Many environmental sociologists have used the theory of metabolic rift to explain shifts in nutrient cycling under capitalist agriculture as Marx did (Clark and York, 2008; Foster, 1999, 2000; Foster and Magdoff, 2000), as well as the ways that sustainable agriculture might help to overcome this rift (Clausen, 2007; Clow and McLaughlin, 2007; Foster and Magdoff, 2000). Others have expanded the scope of analysis to include broader ecological crises: global warming (Clark and York, 2005; York et al., 2003), fisheries depletion (Clausen and Clark, 2005) and the ecological succession arising from the development of global capitalism (Moore, 2000; Prew, 2003). Despite Marx's conception of social metabolism as a fundamentally socio-ecological process, however, most scholarship on metabolic rift has emphasized the ecological dimensions of crises of capitalist accumulation.

If, as Marxian geographers and political ecologists have argued, understanding 'socio-natures' (such as cities, agricultural landscapes or other areas of resource extraction) is contingent upon uncovering the ways in which social and natural processes are co-produced through social metabolism (Harvey, 2006; Smith, 2008; Swyngedouw, 2006), then understanding UA's contingency on historical processes is a necessary first step in theorizing its multiple geographies. The purpose of this paper is therefore two-fold. First, I contribute to the existing conceptualization of metabolic rift by more explicitly emphasizing its social dimensions. I discuss three interdependent yet distinct forms or dimensions of metabolic rift: (i) ecological rift, which includes both the rift in a particular biophysical metabolic relationship (such as nutrient cycling) and the spatio-temporal rescaling of production that follows in its wake; (ii) social rift, arising from the commodification of land, labour and food at various scales and (iii) individual rift, the alienation of humans from nature and from the products of our labour. Rather than a triad of sepa- rate processes, these three unified dimensions of metabolic rift are co-produced but can be differentiated as a function of both the scale at which metabolic rift occurs and by the grain and extent of observation. I should stress here that my intention is not to toss out new terms and concepts simply for the sake of adding to an already saturated lexicon of Marxian political economy. Rather, I hope to bridge and clarify existing concepts and incorporate them into a single framework that accords equal weight to ecological and social aspects. As such, a theory of metabolic rift emphasizing its multiple dimensions may be used more precisely to analyse and explain historical and contemporary transformation of the agri-food system.

My second goal in this paper is to use this expanded view of metabolic rift both to shed light on the different dynamics driving the emergence of UA in various parts of the world and to show how UA attempts to overcome these three forms of metabolic rift. With added emphasis on social rifts in metabolism operating at multiple scales, this expanded framework can help us understand both social and ecological dimensions of UA's multifunctionality, from its attempts to overcome disruptions in ecological cycles to its ability to reclaim public space, re-embed food production and consumption with socio-cultural significance and reconnect consumers with their food and the environment. ${ }^{2}$ Understanding UA in this way may be of service not only to academics but also to policy makers, planners, non-profit workers and UA advocates as they frame discussions of UA and develop future policy and programmes.

\section{Ecological rift: rescaling metabolism}

The form of metabolic rift most discussed by scholars is what I refer to more specifically as ecological rift. According to their arguments, the imperative of spatial expansion inherent to capitalism has cleaved a rift between city and country, humans and nature. In search of new spaces for ongoing accumulation, capital has also disrupted sustainable biophysical relationships such as nutrient cycles. As Moore (2000, 137) argues, "systemic cycles 
of agroecological transformation" triggered by new modes of capitalist production "usher in a new more intrusive and more globalized exploitation of nature by capital'". Capital's ongoing expansion therefore creates a cycle of 'rifts and shifts' whereby attempts to address a metabolic rift in one place simply lead to 'geographic displacement' of ecological crisis (Clark and York, 2008). In an often-cited example, the expansion of capitalist agriculture in Europe and North America led to a soil fertility crisis during the 19th century. A mad dash for new sources of fertility ensued (notably for South American guano and saltpeter) alongside a nascent synthetic fertilizer industry. The scramble to locate new sources of fertility drove imperialist expansionism that ultimately displaced the metabolic rift elsewhere (Clark and York, 2008; Foster, 1999; Foster and Magdoff, 2000). As Engels explained in the late 19th century, each technological triumph over nature leads to other crises: "For each such victory takes its revenge on us. Each victory, it is true, in the first place brings about the results we expected, but in the second and third places it has quite different, unforeseen effects which only too often cancel the first" (Engels, $1959,12)$. These short-term technological fixes inevitably generate new metabolic rifts, amounting to a "a shell game with the environmental problems [capitalism] generates, moving them around rather than addressing the root causes" (Clark and York, 2008, 14).

However, this shell game is not just a matter of space but also a matter of scale. While a rift in a particular metabolic process occurs at a particular scale, social metabolism of nature continues at new spatial and temporal scales as production is relocated or becomes dependent on new inputs. Capitalist rationalization of agriculture (farm consolidation, separation of crops and livestock, the advent of imported and synthetic fertilizers) arose from the pursuit of new markets and from the need to avert crises of production, such as falling rates of profit due to competition, a decline in availability of raw materials or environmental pollution and declining worker health resulting from production practices (cf Moore 2000, 2008). These shifts in production not only severed particular metabolic interactions such as on-farm cycling of nutrients between soil, crops, livestock, manure and human waste but also rescaled social metabolism, both spatially and temporally.

Sustaining social metabolism under a food production system that depletes rather than regenerates the resource base depends on both spatial and temporal rescaling and increasingly relies on what ecologists refer to as spatial and temporal 'subsidies' to the food web (Polis et al., 2004). Whenever metabolism is rescaled to incorporate a new subsidy, a new ecological rift is created because it is impossible to close the loop between the source and sink of the subsidy. During the aforementioned crisis in soil fertility, guano and nitrates imported from Peru and Chile were mined from decades- and centuriesold deposits (Clark and York, 2008; Foster and Magdoff, 2000). If, as Huber $(2009,108)$ argues, fossil fuel use is "an internal and necessary basis to the capitalist mode of production", such spatiotemporal rescaling of social metabolism is also internal and integral to the contemporary agri-food system. The natural gas and petroleum needed to produce synthetic fertilizer and power tractors, for example, is millions of years-old, drawn from gas fields and oil wells around the globe and shipped to factories and refineries before being used thousands of miles from the point of extraction. ${ }^{3}$ It soon becomes easy to see how ecological rift scales up, making social metabolism a global affair, dependent on millions-year-old subsidies from tens of thousands of miles away.

Rescaling these nutrient cycles and reducing dependence on petroleum-based food production lie at the heart of UA's potential to mitigate metabolic rift. British agronomist Sir Albert Howard (1943), concerned that organic wastes (human, animal and crop residues) were rarely cycled back to their point of origin in large-scale agriculture, plaintively pondered, "Can anything be done at this late hour by way of reform? Can Mother Nature secure even a partial restitution of her manurial rights?" (40). While unclear if he was aware of Marx's views on social metabolism (and if so, it is doubtful that as a servant of the British crown he would have 
admitted as much!), Howard echoed the concerns of Liebig, Marx and Engels. Noting that "the Chinese have maintained soil fertility on small holdings for forty centuries" and inspired by the traditional farming practices he witnessed around him in the colonies, Howard championed compost use over chemical fertilizers and pondered a possible transformation of the industrial model where waste would be cycled back to farmland. Howard's notion dovetailed with what Engels envisioned in 1878:

[A]bolition of the antithesis between town and country is not merely possible. It has become a direct necessity of industrial production itself, just as it has become a necessity of agricultural production and, besides, of public health. The present poisoning of the air, water and land can be put an end to only by the fusion of town and country; and only such fusion will change the situation of the masses now languishing in the towns, and enable their excrement to be used for the production of plants instead of for the production of disease. (Marx and Engels, 1978, 723)

In this same tradition, mending ecological rift via the recycling of organic waste is central to UA across the globe. This concept of returning nutrients to agricultural soils in the form of urban waste is vital to overcoming the 'antithesis between town and country' and is fundamental to a 'restitutive' agriculture. While few urban planners and mainstream development practitioners likely look towards Marx and Engels for inspiration, these obscure passages describing metabolic rift are particularly prescient, relevant not only to the development of sustainable agriculture but also to urban waste management and the impending environmental crises of mega-urbanization (cf Davis, 2006, 121-50).

For millennia, farmers worldwide have maintained soil fertility on small plots through the application of organic waste; urban farmers are no exception. Adapting to the rising cost of chemical fertilizers and stagnant market prices for their produce, urban farmers in many parts of the South rely on intensive applications of manure from urban and peri-urban livestock production, ash and composted garbage as a free or low-cost fertilizer and soil conditioner. Peri-urban livestock producers, in addition to tapping rising urban demand for meat, dairy and eggs, sell manure to urban market gardeners and to large-scale vegetable farms in the urban outskirts. To profit from compost's fertilizing potential, farmers frequently cultivate the peripheries of garbage dumps or establish illicit contracts with garbage truck or cart drivers to obtain compost for their fields, paying them to simply dump a load of garbage in their fields while en route to central collection facilities. Advocates argue that redirecting the organic fraction of waste streams to agricultural production in urban areas and their hinterlands will help to boost soil fertility, as well as reduce soil and water pollution arising from heavy agrochemical use and large concentrations of waste deposited in landfills, dumps and waterways (Dreschel and Kunze, 2001; UNDP, 1996).

Yet to truly close the nutrient cycle and diminish the impacts of this ecological rift, human waste from urban consumers would need to be returned to the crops' fields of origin. Every day, on average, every human produces 1 to $1 \frac{1}{2} \mathrm{~kg}$ of nutrient-rich feces. Human waste, or 'night soil', is a common source of organic fertilizer in UA and peri-UA, though less commonly promoted (much less discussed) due cultural biases and to the higher public health risks associated with its application. Despite the social stigma, foul odor and contamination risk related to its use, there is stiff competition among farmers for access to night soil. In one study, twothirds of farmers surveyed in two peri-urban zones in northern Ghana used human waste in their fields (Cofie et al., 2005). In China, in particular, application of human waste to farmland has been central to both urban waste management and agricultural production but has been diminishing as rapid industrialization and urbanization transform agricultural production at the urban edge (UNDP, 1996).

In the Global South, such forms of restitutive soil fertility management generally arise from creative exploitation of limited resources and adaptation to limited access to land, fertilizer and credit. Framed as a sustainable way to reduce urban ecological 
footprints, such age-old nutrient cycling practices (excepting night soil application) are now a cornerstone of UA advocacy worldwide. In North America and Europe, an ethos of agricultural sustainability generally informs UA practice. Many urban gardeners and most UA projects use ecological methods that attempt to close the nutrient cycle, such as compost application, planting of nitrogenfixing cover crops and incorporation of crop residues. Application of compost to urban soils can also provide other environmental services, such as reducing erosion, improving drainage and water holding capacity, controlling pathogen and immobilizing heavy metals. For commercial growers in peri-urban areas, a growing consumer demand for local and organic food often drives the transition to more ecologically sound farming practices. A growing number of municipalities collect green waste (a combination of yard trimmings and food scraps) for composting. Much of the compost is sold at low cost or provided for free to local farmers, landscapers and gardeners.

Infrastructure for the collection, composting and distribution of compost seems to be the greatest hurdle preventing UA's ability to minimize ecological rift in nutrient cycling. Nevertheless, development workers and planners are optimistic about its role and argue that with improved waste management technology, access to land and policies favouring agricultural production in urban areas, UA can contribute significantly to feeding the world's cities and mending ecological rift by restoring 'Nature's manurial rights', rescaling production to a more local level and relying less on spatial and temporal subsidies.

\section{Social rift: commodification}

Drawing on Marx's analysis of soil fertility depletion, most scholars have emphasized ecological dimensions of metabolic rift. According to Marx's conception of social metabolism, however, ecological rifts develop in conjunction with social processes, notably the rise of wage labour. If, as Marx argued, understanding these rifts depends on understanding the linkages between wage labour and capital, the utility of metabolic rift as a theoretical framework through which to view the agri-food system stands to gain from added emphasis on what I call 'social rift'. Two historically interrelated processes - theorized by Marx as primitive accumulation-are central to social rift: the commodification of land and the commodification of labour. The clearing and/or dispossession of subsistence farmers and herders from common land has resulted in the proletarianization of rural populations who flood into urban centres in search of work: "the systematic theft of communal property was of great assistance ... in 'setting free' the agricultural population as a proletariat for the needs of industry', (Marx, 1976, 886). ${ }^{4}$

Understanding this social rift is not only essential to explaining urbanization but also to elucidating the linkages between urbanization and the agri-food system. The rise of large- and industrial-scale farming has entailed the consolidation of land and expansion of mechanization and other new farming technologies, both of which reduce the demand for agricultural labour. This was evident in Europe at the dawn of the capitalist era, in the USA during the latter half of the 20th century (Cochrane, 1993; Mazoyer and Roudart, 2006), and more recently in China where as many as 70 million farmers were dispossessed by expanding land markets in the last decade of the 20th century (Harvey, 2005, 146-7). In the Global South, a host of pressures-structural adjustment programmes, land consolidation, drought, war, expansion of natural resource extraction and biofuels plantations-has dispossessed rural populations over the last several decades and fuelled the growth of megacities and their slums across the globe (Davis, 2006). Indeed, as Marx (1976) predicted, "Part of the agricultural population is therefore constantly on the point of passing over into an urban or manufacturing proletariat" (795).

Social rift is a central driver of UA in the Global South, where production of food is often a subsistence activity. Between 70 and 75 per cent of farmers in a survey of UA in Nairobi, for example, produced for household consumption, citing hunger and the need for food as their principal motivation (Ali 
Memon and Lee-Smith, 1993; Freeman, 1991). Similar rates have been found in other parts of Africa, with lower rates in Asia and Latin America (Egziabher et al., 1994; Mougeot, 2005; van Veenhuizen, 2006). Rural migrants often discover on arrival in urban centres that prospects for employment are slim. Many must therefore improvise new means of survival, particularly in those cities where social services were gutted under structural adjustment during the 1980s and 1990s. Many embark on smallscale agriculture on marginal plots of land tucked in between housing, industry and infrastructure, within the city itself or in its immediate hinterlands, in order to buffer themselves from the socio-economic upheaval of dispossession from their land and from the lack of formal employment opportunities in the city and its peripheral slums. ${ }^{5}$ The slashing of government jobs under structural adjustment in many parts of the Global South also drove members of the urban professional class to embark on UA projects to augment their diets, and for those selling on informal local markets, to supplement their income.

According to Guyer (1987), subsistence and small-scale urban food production, along with the informal food economy to which it contributes, often undermine the expansion of more formal markets. At the same time, however, self-provisioning effectively subsidizes the cost of social reproduction within the larger capitalist economy (Arrighi, 2008; Berry, 1993; Hart, 2002; Wolpe, 1972); in short, wages can stay lower if workers are feeding themselves, ultimately facilitating the accumulation of capital. ${ }^{6}$ UA therefore exists in tension with capital, arising as a strategic response to social rift on one level by exploiting underutilized land and buttressing against the expansion of commercial agri-food markets in poor areas, while subsidizing ongoing accumulation on a more macro-level. Such coping mechanisms generally shift an additional burden onto the shoulders of urban women, in particular (Hovorka et al., 2009; Meillassoux, 1983). In addition to expending her energy on food production and jobs in the informal economy, a female farmer may also divert income earned from sale of surplus produce towards the purchase of additional ingredients for a meal; as a Senegalese extensionist explains, "Whatever a woman earns [from her gardens] goes directly into the cooking pot" (McClintock, 2004).

A straightforward Marxian analysis of the combined impact of low wages and dispossession from the land can largely explain the rise of UA and its continued presence in the Global South. Indeed, primitive accumulation is ongoing as Southern countries integrate more fully into the global economy and communally managed property 'enclosed' by titling arrangements and emerging land markets. In the North, however, such processes happened longer ago; it is therefore helpful to draw also on the work of Polanyi (2001) in order to understand how social rift has produced UA in the North. Polanyi describes in detail how land, labour and money are bought and sold as 'fictitious commodities', fictitious because they were not produced to be sold as a commodity. Under the expansion of laissez faire economic liberalism, they are increasingly subject to the whims of the free market (Polanyi, 2000, 60). In times of economic crisis, when the market value of the fictitious commodities fluctuates dramatically, an 'avalanche of social dislocation' tends to follow (Polanyi, 2000, 42). Polanyi argues that without a moral economy of mutual aid in times of need, the unchecked buying and selling of these fictitious commodities risks unleashing social upheaval:

Robbed of the protective covering of cultural institutions, human beings would perish from the effects of social exposure .... Nature would be reduced to its elements, neighborhoods and landscapes defiled, rivers polluted ... the power to produce food and raw materials destroyed. (Polanyi, 2000, 76)

Wages left to laissez faire or free market logic decline as surplus labour enters the market (a process that, as we have seen, is fueled by the ongoing primitive accumulation), depressing wages that lowers work and living standards (Marx, 1976; Harvey, 2007). Land-and by extension natural resources-valued only as a production input or commodity for exchange can be over-exploited 
for short-term gain with little consideration of its long-term productivity. In sum, "leaving the fate of soil and people to the market would be tantamount to annihilating them" (Polanyi, 2001, 137). To protect people from extreme social dislocation, a 'protective counter-movement' inevitably arises (Polanyi, 2001, 71-80) that ranges in form from communal networks of support to government intervention and regulation.

With the rise of rapid urbanization during the industrial era, UA repeatedly arose as part of a counter-movement to protect the population from the social dislocation resulting from "leaving the fate of soil and people to the market'". Subsistence food production was part of the American and $\mathrm{Eu}-$ ropean urban landscapes well into the 20th century. As urban areas developed during industrialization, UA often served as a coping strategy, significantly subsidizing the social reproduction of workers as in the South. In Britain, the Commons Act 1876 and various Allotment Acts (1832, 1887, 1908, 1922, 1925 and 1950) obliged ocal governments to provide citizens with space for food production (Crouch and Ward, 1988). In the USA, subsistence production was actively practised and encouraged well into 20th century in urban centres such as Los Angeles, where chickens, pigs, beans and tomatoes were common sights in the small yards of worker housing (Nicolaides, 2001). Community gardens in the USA and allotment gardens in the UK grew in number during times of economic hardship and austerity. However, the growth of UA during these crises periods was often orchestrated by governments as a part of a coordinated protective measure. Urban food production served not only to buffer for food security but also to quell potential unrest (Moore, 2006). As America industrialized in the late 19th century, a growing pool of unemployed gathered in urban areas. Municipal governments provided garden plots and seeds to stave off hunger and unrest. During the Depression of 1893, the mayor of Detroit launched a so-called Potato Patch plan-later adopted across the USA-to provide the unemployed with vacant lots between $1 / 4$ and 1 acre each. More than 1500 families farmed small vacant lots between an eighth- to a half-hectare each on 455 acres (184 ha). Gardens were intended not only to provide food and employment but also to create self-respect and to help assimilate recent immigrants. During the Great Depression, UA again provided food and jobs for the masses of unemployed. The New Deal Federal Emergency Relief Administration spent $\$ 3$ billion on relief gardens between 1933 and 1935 alone. One gardening programme in New York City transformed 5000 vacant lots into highly profitable gardens by 1934 (Brown and Jameton, 2000; Lawson, 2005).

Garden programmes also exploded during wartime. Liberty gardens proliferated in the USA during the World War I as a government response to the food riots gripping the nation. Under the guidance of the National War Garden Commission, 'idle' land was cultivated by more than 5 million gardeners. During World War II, under the National Victory Garden Program, 20 million gardens produced 40 per cent of America's vegetables by 1944 . During the economic recession of the 1970s, 'inflation gardens' flourished in America's inner cities with a boost from the back-to-the-land ideals of the environmental movement and the USDA's \$1.5 million Urban Gardening Program. During this period, community gardeners and activists took over thousands of vacant lots in US cities that had become fallow in the ebb of industrial and residential capital (Brown and Jameton, 2000; Lawson, 2005; Schmelzkopf, 1995).

This same notion of local food production as a safety net for city dwellers drives many of today's initiatives. Leon Davis, a community activist in Oakland, California, explains:

Food is the key, food is the gold. Even when people get kicked out of their apartments and they're out there homeless on the street, they're still going to have to acquire food. For people out on the streets, how can they get fed for that day? "When my stomach get growling, man, and I don't have no money in my pocket, I'll go steal something out the store," you see? So if you don't establish a network with food as a basis, you're going to have more thieving, more people are going be stealing from stores, robbing people 
because they don't have no money, so they can buy food. Not so they can buy drugs, but so they can buy a sandwich. People robbing each other so they can buy a sandwich. So food production needs to ramp up. More local farms, not just in the outlying areas, but right here in the city, people growing, knowing how to grow. (Interview with the author, 16 March 2009, Oakland, California)

As Davis argues in the quote above, local food production is central to a local food system that is accessible to all and is necessary in order to stave off precisely the sort of social dislocation arising from economic crisis that Polanyi warned of. The Obama administration is on the same page and has launched a Keynesian protective countermovement vaguely reminiscent of the Franklin Roosevelt's New Deal to stave off the social upheaval due to widespread unemployment. Evidently, the US government is once again onboard in the promotion UA as a means of guaranteeing food security for the urban poor. Following the precedent set by the First Lady's South Lawn garden, the Corporation for National and Community Service, the public-private partnership housing AmeriCorps and other government-sponsored domestic volunteer programmes, published an online 'toolkit' on how to establish a community garden as a means to 'expand access to healthy local food'. The document explains:

Community gardens provide access to traditional produce or nutritionally rich foods that may otherwise be unavailable to low-income families and individuals .... Community gardens allow families and individuals, without land of their own, the opportunity to produce food. Oftentimes gardeners take advantage of the experiential knowledge of elders to produce a significant amount of food for the household. ${ }^{7}$

The discourse of crisis driving these programmes was used not only to justify UA but also to denigrate it as an act of welfare for the poor once crises had passed. As such, crisis discourse helped to ob- scure the subsistence role that UA has always played in urban landscapes, as well as to devalue UA in times of prosperity (Moore, 2006). Indeed, when the economy improves and adjacent land values rise, UA is no longer seen as a public good but an obstacle to development. In New York's Lower East Side during the 1970s, for example, municipal government promoted community gardens as "a productive use of land considered to be relatively useless'. The gentrification of nearby SoHo in the 1980s, however, led to rising land values and a growing interest in development and eventually to a moratorium of leasing vacant land for gardens and the bulldozing of several squatter gardens. Tensions also arose within the community over whether to use vacant lots as space for gardens or for lowincome housing (Schmelzkopf, 1995). These tensions between development and UA are often racialized, as in the case of South Central Farms. The 14-acre farm was originally established in 1993 by the Los Angeles Regional Food Bank in an effort to bring healthy food to the impoverished neighbourhood. In a now-famous case, the gardens (which provided food for more than 350 families) were bulldozed in 2006 following a long legal and political battle between activists, city council and the land owner (Barraclough, 2009; Irazábal and Punja, 2009). ${ }^{8}$

UA's relation to social rift does not lie with land alone. If we consider food as a fictitious commodity like land, UA's ability to mend social rift becomes even clearer. Food, while produced as a commodity in the capitalist agri-food system, functions in a similar manner to Polanyi's other fictitious commodities. Its treatment as a simple commodity to be bought and sold according to market logic effaces the complex weave of relations running through its production, distribution, preparation and consumption. The rapid transformation of the agri-food system during the 20th century was due in large part to the expanded commodification of food, from patented seeds to artificial ingredients and fast food restaurants. As food has become increasingly processed and packaged, the culture and traditions surrounding food production and consumption have gradually been obscured by the market-based 
ideology of cheap food (Levenstein, 2003; Schlosser, 2005).

The socio-cultural significance of food and agriculture rarely factors into calculations of profit margins; certain social relations woven into the agri-food system - for example agricultural and culinary knowledge and its cultural significance-are impossible to quantify and either resist commodification or are erased by a commodified agri-food system. Since the middle of the last century, the commodification of food has systematically unravelled many of these existing social relations and created new commodity-driven relations of production and consumption that "undermine the source of all wealth-the soil and the worker"' at multiple scales (Marx, 1976, 638). Farming has evolved into a highly specialized industry based on inputs and outputs and which engages less than 2 per cent of the US population; over-application of agrichemicals have poisoned farmworkers and created a massive 'dead zone' in the Gulf of Mexico; agricultural and culinary knowledge have been lost; diabetes, heart disease and obesity have followed on the heels of junk food consumption worldwide.

As a protective counter-movement, UA attempts to mitigate social rift by de-commodifying land, labour and food. Various case studies in North America have illustrated how gardens are a site of interaction between various ages and ethnic groups, where knowledge about food production and preparation is shared and community ties strengthened (Baker, 2005; Irazábal and Punja, 2009; SaldivarTanaka and Krasny, 2004; Shinew et al., 2004). UA produces new commons, by returning-at least partially-the means of production to urban populations. The verdure emerging from cities' marginal spaces—road medians, infrastructure rights of way, vacant lots, wasteland - signals both a reclamation of what remains of the commons and the creation of new commons from the interstitial spaces skipped over by capital or left fallow in its retreat. In Europe and North America, movements to redevelop industrial brownfields as urban green space offer possibilities for scaling up UA (DeSousa, 2004; Rosol, 2005). While the forces giving rise to UA differ between the Global North and South, UA joins together these tiny tesserae into a fertile mosaic in both places, where gardens grown along the abandoned railroad right of way in Detroit are not unlike those growing alongside rusted rails in Dakar. Goats and cattle graze weeds growing up amid the cement blocks and rebar of all-but-abandoned buildings. A bean patch is tucked in the 3 metre wide strip of road shoulder between the asphalt and the wall of a government building. An abandoned racetrack is a patchwork of vegetable gardens from a nearby drainage ditch.

The commons are not solely the vacant spaces and wastelands of the world's cities but include all agricultural resources and foodways that have been commodified (or lost to substitution by a commodity)_land, seeds, water, soil fertility, biodiversity, agricultural and culinary knowledge. Several case studies note the biodiversity and knowledge conserved in urban gardens, particularly by immigrant groups, despite the difficulties in retaining these spaces in a commodified landscape where land value trumps usufruct rights and municipal codes are often at odds with farming practices such as compost production, wastewater recycling and small livestock husbandry. ${ }^{9}$ As Johnston (2008) argues, alternative food movements such as UA can ultimately reclaim these once-common resources from the enclosure of capitalist commodification by:

ensur[ing] that access to basic life-goods like food can be met through non-commodity channels, particularly when sufficient purchasing power is lacking .... Reclaiming the commons does not necessarily mean that markets and individual consumption styles are eradicated, but it does demand that markets be reembedded in social structures that ensure that nutritious, sustainable food goes not only to those who can afford it but to everyone. (100-101)

For many forms of UA, this sort of Polanyian counter-movement amounts to a wresting away of food production and consumption from the market via the valorization of unquantifiable socio-cultural values and relations traditionally inherent in food. 
For guerrilla gardeners and food justice advocates, it more explicitly represents a radical rejection of a commodified agri-food system via the appropriation of land and labour for purposes other than the accumulation of capital.

\section{Individual rift: alienation}

Social and ecological dimension alone cannot fully explain the rise of UA in the North. For many, a certain lifestyle politics drives the attraction to the urban farming; 'getting in touch with nature' or 'learning where our food comes from' is a common trope. It is important then to hone in on how metabolic rift impacts the individual consciousness. As a broader social rift is cleaved by the commodification of land and labour, people experience an internalized dimension of metabolic rift, which I refer to as 'individual rift'. Essentially what Marx called alienation [Entaüsserung] from labour and from nature, it manifests as the perception of self as external to the environment. While this dimension of metabolic rift is perhaps the most difficult to overcome due how deeply rooted it is in the social processes outlined above, individual rift can be addressed-and potentially overcome-through UA more easily than can other forms of rift precisely because it arises at the level of the individual consciousness. Two interrelated forms of alienation are central to individual rift: alienation from labour and alienation from nature. First, individual rift arises from our alienation from the fruits of our labour. As discussed above, the social rift in metabolism arises from the commodification of labour and the separation of the worker from the means of production (for example the land). At the same time, under capitalist production, a wage labourer no longer owns the finished product he or she creates. Rather than producing something for his or her own use, the worker produces it for the capitalist (for example an agribusiness corporation) to sell as a commodity to earn profits used to fuel further accumulation. As Sohn-Rethel (1978, 109-16) argues, the root of this alienation lies in the division of intellectual and manual labour, a long historical process cemented at the dawn of capitalism via the rationalization of labour and which intensified individual rift. ${ }^{10}$ The later 'Balkanization of knowledge' into social and natural sciences encouraged the division of labour, further alienating humans from nature as a result of the "inadequate understanding of how these knowledges connect with one another in the process of producing the concrete outcomes in which we are interested" (Dickens, 1996, 21). Due to this division of manual and intellectual labour, the rationalization of production through technological advances and the de-skilling of labour have further alienated the worker from the product and the whole process of production. In short, the more that science enters into production, the less the worker understands about the process of production and the more his or her creative capacity is undermined (Braverman, 1974, 428).

Second, the separation from land as discussed in the previous section is central to individual rift. From both ecological and Marxian perspectives, humans simultaneously shape and are shaped by the ecosystems to which we belong. More specifically, we are the nature around us. Nature is, Marx theorized, integral to human life and development (Dickens, 1996, 57) As Mészáros (2005, 124) explains, "the historically primary relationship between man and nature [is] nature's relation to itself, on the grounds that man is a specific part of nature". Since "earth is the first condition of man's existence, land is, of course, absolutely inalienable from man" (Mészáros, 2005, 134), and by extension, inalienable from all sorts of non-quantifiable social significance; precisely why Polanyi considered it inseparable. It follows, then, that the expropriation and commodification of land and nature-a process central to the cleaving of social rift—rends not only a material rift between land and labour but also an internalized rift in our cognitive and experiential understanding of ourselves as functional organisms existing as a part of a larger ecosystem. ${ }^{11}$

This alienation from nature is well documented in developmental psychology, education and evolutionary biology, as well. The shift from direct to 'increasingly abstract and symbolic' contact with the outside environment in the contemporary political economy (Orr, 2002, 291) limits affective, 
cognitive and evaluative development in children (Kahn and Kellert, 2002), leading to a rise in childhood behavioural problems, popularly referred to as 'nature deficit disorder' (Louv, 2008). Several studies have concluded that exposure to vegetation and green space is essential to children's cognitive development, can reduce attention deficit disorder and reduce crime and 'mental fatigue' or desperation in impoverished urban areas (Kuo and Sullivan, 2001; Taylor et al., 2001).

From the Marxian perspective, the de-alienation of humans both from the fruits of our labour and from the natural or biophysical world depends on our active metabolism of nature through labour. By physically labouring the soil, sowing seeds, cultivating, harvesting and preparing food, UA mends individual rift by reengaging individuals with their own metabolism of the natural environment. Not only do experiences in the garden bring the urban farmer, gardener or beekeeper into direct contact with the biophysical environment-soil, plants, water, sunshine, rain, worms, insects, birds-as prescribed by the behavioural scientists cited above, but also allows him or her to experience and metabolize the surrounding landscape, transforming it into a product that he or she can consume. The urban farmer's labour thus sutures individual rift, reintegrating the human with nature as well as de-alienating the labourer from fruit of his or her labour. In this case, labour's fruit is more than metaphor, as it may indeed be a fruit, vegetable, honey, milk, eggs or meat.

Several public health and education studies have linked UA to enhanced natural science and nutritional knowledge and improved mental and physical health (Hermann et al., 2006; Morris and Zidenburg-Cherr, 2002; Pothukuchi, 2004; Twiss et al., 2003; Wakefield et al., 2007). Recent immigrants to the North American cities rely on UA as a means of alleviating boredom and putting their agrarian skills and knowledge to work. For Hmong women in Sacramento, urban gardening "structured their time, and provided a sense of accomplishment, as they grew their own produce, and supplied their children, grandchildren, and families with food", countering the culture shock and feel- ings of dependence and uselessness they felt upon arrival to the USA (Corlett et al., 2003, 377). A study by Airriess and Clawson (1994) on UA practised by Vietnamese refugees in New Orleans reported similar findings. ${ }^{12}$

Such attempts to overcome individual rift by reengaging with the processes of food production and consumption lie at the centre of the UA movement in the Global North. As I argue above, UA arises as a counter-movement in response to economic crisis and to the commodification of land and labour. Yet viewing UA in this way alone does not fully grasp UA's multiple origins, functions and forms. Focusing on individual rift-particularly in the North where there is a longer history of alienation from manual labour and the biophysical environment-helps to illuminate the important role that UA serves in late capitalist economies while differentiating its various forms. While guerrilla gardening and food justice initiatives may arise from an explicitly counter-hegemonic challenge to the capitalist food system as described in the previous section, the groundswell of interest in community gardens backyard and community gardening appears to be largely linked to efforts to lessen the impact of individual rift. While individual rift is arguably much more widespread in the North than in the cities of the South where linkages to agrarian livelihoods remain intact, within a generation or two, urban dwellers in the South may also experience similar alienation from their food. The words of a young woman from Bamako poignantly illustrate this: "Why should we care about agriculture, about soil erosion? That's the domain of rural peasants" (Personal interview with the author, 6 July 2006, Bamako, Mali).

While I am not arguing that everyone can or should grow his or her own food, my intention is to show how the practices associated with UAtilling, planting, weeding, watering, harvesting, composting - are a force of de-alienation. UA, from this perspective, can help re-establish a conscious metabolic relationship between humans and our biophysical environment by reintegrating intellectual and manual labour. It is also important to emphasize that this dimension of rift is a necessary 
prerequisite to the ongoing expansion of capitalist modes of production. If, as Marx argued, nature is alienable from humans, we can easily make the link between ecological and human health; damage to the environment is therefore damage to one's self. Complacency towards what we would otherwise perceive as self-destructive actions is contingent on individual rift; to perceive and experience environmental degradation as a solely external process rather than one simultaneously internal and external depends on this alienation. Recognizing this form of rift and understanding the forces that cleave it is therefore an essential first step.

\section{Conclusions}

As I have shown in this paper, metabolic rift has three interrelated and interdependent dimensionsecological, social and individual-operating at multiple scales. Understanding these dimensions of metabolic rift this way is valuable for both theory and practice. The traditional emphasis on cycles of environmental degradation used by most metabolic rift theorists can help to illustrate how ecological crisis is rescaled upwards and outwards due to the expansionary logic of global capital, but a singular focus on this ecological dimension may be crippling. While it may elucidate the agri-food system's dependency on cross-scalar ecological subsidies, it may fail to identify the fault lines and fractures in such a system that an added focus on individual and social dimensions of metabolic rift can offer. It is precisely along these fault lines that practices such as UA arise and where policy makers, planners, non-profit workers and UA advocates alike may locate and seize opportunities to transform the agri-food system into one more equitable, healthy and ecologically sustainable. While metabolic rift is arguably irreparable within the logic of a capitalist system, using this multidimensional framework may better reveal the locations of these potential points of engagement.

In addition, understanding UA through this lens not only helps to explain how and why UA arises in different parts of the world but may also reveal opportunities for its expansion as part of a growing network of local food systems. As we have seen, UA frequently arises as a protective countermovement at a local level from the inevitable crises of capitalism (such as the one in which we find ourselves currently) unfolding at the global level. A certain momentum develops, however, whereby these small-scale movements-occurring as an inchoate patchwork of local sites-evolve into a semi-coordinated force, spurred on by increasing public visibility and eventually, regional or national level support. North-North, SouthSouth and North-South associational linkages have also helped to mobilize support for UA. Urban farmers and UA policies in the South have served as models for UA activists in the North; similarly, media, resources and technical information from Northern organizations such as the Resource Centres on Urban Agriculture and Food Security and the Centre for Learning on Sustainable Agriculture have benefited UA extension work in the South. Understanding the social dimensions of UA is critical to any such transformation. As I argue above, de-commodifying food, the land on which it is grown and the labour with which it is produced first requires attention to individual rift; the de-alienation of humans from the biophysical environment is a necessary prerequisite. This may occur either via individual engagement or via formal or informal efforts to reintegrate humans and nature, and intellectual and manual labour, through experiential education and praxis. A de-alienated population provides the critical mainstay of support for ongoing resistance to the inevitable attempts at re-commodification. Crucial then is the creation and protection of a new agrarian commons created among the urban fallows, the cultivation of associational linkages between urban producers and consumers and investment in other policy frameworks and infrastructure necessary to promote urban food production as a multifunctional practice. Indeed, UA should be framed and supported in a way that addresses the multiple dimensions of metabolic rift. These first important steps towards the gradual "abolition of the antithesis between town and 
country', intellectual and manual labour, humans and nature, are underway in urban gardens worldwide. The ability to scale it up remains to be seen. Promoting the growth and vitality of these urban agricultural spaces through coordinated policy, planning and action across scales-from individual decision making to municipal planning to national and global policy-remains the grand task ahead.

\section{Endnotes}

${ }^{1}$ For a detailed reviews of the history of 'metabolism' and its use as a conceptual theory, used first by natural scientists and later by Marx and other social scientists, see Foster (1999, 2000) and Heynen et al. (2006). Marxian geographers and political ecologists have further advanced Marx's theory of metabolism by showing how social processes produce nature (Harvey, 2006; Smith, 2008; Swyngedouw, 2006).

2 The origins of this paper actually lie in the use of metabolic rift as a pedagogical tool to explain UA's multifunctionality in both the Global South and North. For 3 years, I co-taught an undergraduate course on UA in which we used the theory to frame our interdisciplinary study of urban agroecosystems. It enabled us to bridge disciplinary divides, linking social science analyses of urbanization and the rise of the industrial agri-food system to biophysical science understandings of soil and insect ecology and a hands-on laboratory practicum in which students grew their own food. Framing the course this way allowed students to understand-both intellectually and experientially - how UA simultaneously arises from metabolic rift and attempts to overcome it. Similarly, this framework has helped me make sense of the various forms of UA I have encountered in the field both a researcher and extensionist working in the USA, Latin America, West Africa and South Asia over the last decade.

${ }^{3}$ Engels noted this temporal shift occurring under capitalist modes of production: " the working individual is not only a stabilizer of the present but also, and to a far greater extent, a squanderer of past, solar heat', (Engels in Foster, 2000, 166).

${ }^{4}$ It is crucial to understand that primitive accumulation is not a process solely relegated to the 'pre-history of capitalism' but is an ongoing process of commodification of public goods and spaces that extends beyond the histor- ical enclosure of the commons centuries ago (DeAngelis, 2004). This 'accumulation by dispossession' (Harvey, 2003) of resources is visible as contemporary markets expand to incorporate such diverse commonly held resources as water, genes and knowledge (Goodman et al., 1987; Kloppenberg, 2005).

5 Davis (2006) describes the 'urban involution' occurring in many cities of the Global South where population growth outpaces economic growth, leading to the expansion of the informal economy and more extreme forms of self-exploitation necessary for survival.

${ }^{6}$ Self-exploitation and the resulting deflection of reproduction costs therefore allow accumulation to also take place without dispossession, as Hart (2002) and Arrighi (2008), and Berry (1993) have argued.

7 Online: http://www.serve.gov/toolkits/comm-gardens/ index.asp (accessed 22 June 2009).

${ }^{8}$ Paradoxically, urban gardens that arise from undervalued vacant land may ultimately contribute to the rising property values adjacent to the gardens (Voicu and Been, 2008), ultimately threatening their tenure.

${ }^{9}$ See Corlett et al. (2003) on biodiversity and agricultural knowledge in Hmong gardens in Sacramento. Airriess and Clawson (1994) describe how Vietnamese gardeners in New Orleans burn crop residues to fertilize soil in violation of city codes.

${ }^{10}$ According to Sohn-Rethel's analysis, the alienation of the worker from his or her product did not necessarily arise solely in the capitalist era but was an ongoing historical process that—while beginning in the classical era with the development of Euclidean geometry-grew wider during the Renaissance era. The 'unity of head and hand' inherent to artisanal production slowly diminished as design became the domain of mathematicians, engineers and military architects and basic construction left to craftsmen.

${ }^{11}$ Admittedly, alienation from land and labour alone cannot account for individual rift between humans and nature. Geographers and environmental historians have for decades attempted to trace the origins of the human versus nature dualism, ascribing the cleavage to Aristotelian logic and its resurgence during the Age of Enlightenment and to the material development of human powers that allowed for the objective manipulation of nature (Glacken, 1967; Smith, 2008; Williams, 1973, 10-48).

12 It is important to note here that many of these refugees also use UA as a coping strategy to deal with 
persistence of poverty in the neighbourhoods where they were resettled.

\section{Acknowledgements}

Preparation of this article was made possible by fellowships from the Robert and Patricia Switzer Foundation and UC Berkeley's Institute for the Study of Social Change. The author wishes to thank the following people for their comments on earlier drafts of this article: Rachel Brahinsky, Sandy Brown, John Lindenbaum, Seth Lunine, Alex Tarr, Nathan Sayre, Christine Trost, Dick Walker and two anonymous reviewers.

\section{References}

Airriess, C. A. and Clawson, D. L. (1994) Vietnamese market gardens in New Orleans. Geographical Review, 84: 16-31.

Ali Memon, P. and Lee-Smith, D. (1993) Urban agriculture in Kenya. Canadian Journal of African Studies, 27: $25-42$.

Arrighi, G. (2008) Adam Smith in Beijing: Lineages of the Twenty-First Century. London: Verso.

Baker, L. E. (2005) Tending cultural landscapes and food citizenship in Toronto's community gardens. Geographical Review, 94: 305-325.

Barraclough, L. R. (2009) South Central Farmers and Shadow Hills homeowners: land use policy and relational racialization in Los Angeles. The Professional Geographer, 61: 164-186.

Berry, S. (1993) No Condition Is Permanent: The Social Dynamics of Agrarian Change in Sub-Saharan Africa. Madison: University of Wisconsin Press.

Braverman, H. (1974) Labor and Monopoly Capital: The Degradation of Work in the Twentieth Century. New York: Monthly Review Press.

Brown, K. H. and Jameton, A. L. (2000) Public health implications of urban agriculture. Journal of Public Health Policy, 21: 20-39.

Clark, B. and York, R. (2005) Carbon metabolism: global capitalism, climate change, and the biospheric rift. Theory and Society, 34: 391-428.

Clark, B. and York, R. (2008) Rifts and shifts: getting to the root of environmental catastrophe. Monthly Review, 60: $13-24$.

Clausen, R. (2007) Healing the rift: metabolic restoration in Cuban agriculture. Monthly Review, 59: 40-52.

Clausen, R. and Clark, B. (2005) The metabolic rift and marine ecology: an analysis of the ocean crisis within capitalist production. Organization \& Environment, 18: 422-444.

Clow, M. and McLaughlin, D. (2007) Healing the metabolic rift between farming and the eco-system: chal- lenges facing organic farmers in Canada and in Sweden. Journal of the Society for Socialist Studies, 3: 5-21.

Cochrane, W. W. (1993) The Development of American Agriculture: A Historical Analysis. Minneapolis: University of Minnesota Press.

Cofie, O. O., Kranjac-Berisavlevic, G. and Dreschel, P. (2005) The use of human waste for peri-urban agriculture in northern Ghana. Renewable Agriculture and Food Systems, 20: 73-80.

Corlett, J. L., Dean, E. A. and Grivetti, L. E. (2003) Hmong gardens: botanical diversity in an urban setting. Economic Botany, 57: 365-379.

Crouch, D. and Ward, C. (1988) The Allotment: Its Landscape and Culture. London: Faber and Faber.

Davis, M. (2006) Planet of Slums. London: Verso.

DeAngelis, M. (2004) Separating the doing and the deed: capital and the continuous character of enclosures. Historical Materialism, 12: 57-87.

DeSousa, C. A. (2004) The greening of brownfields in American cities. Environmental Planning and Management, 47: 579-600.

Dickens, P. (1996) Reconstructing Nature: Alienation, Emancipation and the Division of Labor. London: Routledge.

Dreschel P, Kunze D. (eds). (2001). Peri-Urban Agriculture: Closing the Rural-Urban Nutrient Cycle in Sub-Saharan Africa. New York: CABI Publishing.

Egziabher AG, Lee-Smith D, Maxwell DG, et al. (eds). (1994) Cities Feeding People: An Examination of Urban Agriculture in East Africa. Ottawa: IDRC.

Engels, F. (1959) The Dialectics of Nature. Moscow: Progress.

Foster, J. B. (1999) Marx's theory of metabolic rift: classical foundations for environmental sociology. American Journal of Sociology, 105: 366-405.

Foster, J. B. (2000) Marx's Ecology: Materialism and Nature. New York: Monthly Review Press.

Foster, J. B. and Magdoff, F. (2000) Liebig, Marx, and the depletion of soil fertility: relevance for today's agriculture. In F. Magdoff, J.B. Foster, and F.H. Buttel (eds) Hungry for Profit: The Agribusiness Threat to Farmers, Food and the Environment. New York: Monthly Review Press.

Freeman, D. B. (1991) A City of Farmers: Informal Urban Agriculture in the Open Spaces of Nairobi, Kenya. Montreal: McGill-Queen's University Press.

Glacken, C. J. (1967) Traces on the Rhodian Shore. Berkeley: University of California Press.

Goodman, D., Sorj, B. and Wilkinson, J. (1987) From Farming to Biotechnology: A Theory of Agro-Industrial Development. New York: Basil Blackwell.

Guyer, J. I. (1987) Introduction. In J.I. Guyer (ed.) Feeding African Cities. Bloomington: Indiana University Press. 
Hart, G. (2002) Disabling Globalization: Places of Power in Post-Apartheid South Africa. Berkeley: University of California Press.

Harvey, D. (2003) The New Imperialism. New York: Oxford University Press.

Harvey, D. (2005) A Brief History of Neoliberalism. New York: Oxford University Press.

Harvey, D. (2006) Spaces of Global Capitalism. London: Verso.

Harvey, D. (2007) Limits to Capital. London: Verso.

Hermann, J. R., Parker, S. P. and Brown, B. J., et al. (2006) After-school gardening improves children's reported vegetable intake and physical activity. Journal of Nutrition Education and Behavior, 38: 201-202.

Heynen, N., Kaika, M. and Swyngedouw, E. (2006) In the Nature of Cities: Urban Political Ecology and the Politics of Urban Metabolism. London: Routledge.

Hovorka, A., de Zeeuw, H. and Njenga, M. (eds). (2009) Women Feeding Cities: Mainstreaming Gender in Urban Agriculture and Food Security. Bourton on Dunsmore: Practical Action Publishing.

Howard A. Sir., (1943) An Agricultural Testament. New York: Oxford University Press.

Huber, M. T. (2009) Energizing historical materialism: fossil fuels, space and the capitalist mode of production. Geoforum, 40: 105-115.

Irazábal, C. and Punja, A. (2009) Cultivating just planning and legal institutions: a critical assessment of the South Central Farm struggle in Los Angeles. Journal of Urban Affairs, 31: 1-23.

Johnston, J. (2008) Counterhegemony or bourgeois piggery? food politics and the case of foodshare. In W. Wright and G. Middendorf (eds) The Fight Over Food: Producers, Consumers, and Activists Challenge the Global Food System. University Park: Pennsylvania State University.

Kahn Jr., P. H. and Kellert, S. R. (eds). (2002) Children and Nature: Psychological, Sociocultural, and Evolutionary Investigations. Cambridge: MIT Press.

Kloppenberg, J. (2005) First the Seed: The Political Economy of Plant Biotechnology. Madison: University of Wisconsin Press.

Kuo, F. E. and Sullivan, W. C. (2001) Environment and crime in the inner city: does vegetation reduce crime? Environment and Behavior, 33: 343-367.

Lawson, L. J. (2005) City Bountiful: A Century of Community Gardening. Berkeley: University of California Press.

Levenstein, H. (2003) Paradox of Plenty: A Social History of Eating in Modern America. Berkeley: University of California Press.

Louv, R. (2008) Last child in the woods: saving our children from nature-deficit disorder. Chapel Hill: Algonquin Books.

Marx, K. (1976) Capital: A Critique of Political Economy, vol. 1. London: Penguin Classics.
Marx, K. (1981) Capital: A Critique of Political Economy, vol. 3. London: Penguin Classics.

Marx, K. and Engels, F. (1978) The Marx-Engels Reader. New York: WW. Norton \& Co.

Mazoyer, M. and Roudart, L. (2006) A History of World Agriculture From the Neolithic Age to the Current Crisis. New York: Monthly Review Press.

McClintock, N. (2004) Women in Senegalese peri-urban agriculture: the case of Touba Peycouck. Urban Agriculture, 12: 25-26.

Meillassoux, C. (1983) The economic bases of demographic reproduction: from the domestic mode of production to wage-earning. Journal of Peasant Studies, 11: $50-61$.

Mészáros, I. (2005) Marx’s Theory of Alienation. London: Merlin Press.

Moore, J. W. (2000) Environmental crises and the metabolic rift in world-historical perspective. Organization \& Environment, 13: 123-157.

Moore, S. (2006) Forgotten roots of the Green City: subsistence gardening in Columbus, Ohio, 1900-1940. Urban Geography, 27: 174-192.

Moore, J. W. (2008) Ecological crises and the agrarian question in the world-historical perspective. Monthly Review, 60: 54-63.

Morris, J. L. and Zidenburg-Cherr, S. (2002) Gardenenhanced nutrition curriculum improves fourth-grade school children's knowledge of nutrition and preferences for some vegetables. Journal of the American Dietary Association, 102: 91-93.

Mougeot LJA. (ed.). (2005) Agropolis: The Social, Political and Environmental Dimensions of Urban Agriculture. Ottawa: IDRC.

Nicolaides, B. M. (2001) The quest for independence: workers in the suburbs. In T. Sitton and W. Deverell (eds) Metropolis in the Making: Los Angeles in the 1920s. Berkeley: University of California Press.

Orr, D. W. (2002) Political economy and the ecology of childhood. In Kahn P.H. Jr and S.R. Kellert (eds) Children and Nature: Psychological, Sociocultural, and Evolutionary Investigation. Cambridge: MIT Press.

Polanyi, K. (2001) The Great Transformation: The Political and Economic Origins of Our Time. Boston: Beacon Press.

Polis GA, Power ME, Huxel GR. (eds). (2004) Food Webs at the Landscape Level. Chicago: University of Chicago Press.

Pothukuchi, K. (2004) Hortaliza: a youth "Nutrition Garden"' in Southwest Detroit. Children, Youth and Environments, 14: 124-155.

Prew, P. (2003) The 21st century world-ecosystem: dissipation, chaos, or transition? In W.A. Dunaway (ed.) Emerging Issues in the 21st Century World-System, vol. 2, London: Praeger. 
Rosol, M. (2005) Community gardens: a potential for stagnating and shrinking cities? Examples from Berlin. Die Erde, 136: 165-178.

Saldivar-Tanaka, L. and Krasny, M. E. (2004) Culturing community development, neighborhood open space, and civic agriculture: the case of Latino community gardens in New York City. Agriculture and Human Values, 21: 399-412.

Schlosser, E. (2005) Fast Food Nation: The Dark Side of the All-American Meal. New York: Harper Perennial.

Schmelzkopf, K. (1995) Urban community gardens as contested space. Geographical Review, 85: 364381 .

Shinew, K. J., Glover, T. D. and Parry, D. C. (2004) Leisure spaces as potential sites for interracial integration: community gardens in urban areas. Journal of Leisure Research, 36: 336-355.

Smith, N. (2008) Uneven Development: Nature, Capital, and the Production of Space. Athens: University of Georgia Press.

Sohn-Rethel, A. (1978) Intellectual and Manual Labor: A Critique of Epistemology. Atlantic Highlands, NJ: Humanities Press.

Swyngedouw, E. (2006) Metabolic urbanization: the making of cyborg cities. In N. Heynen, M. Kaika, and E. Swyngedouw (eds) In the Nature of Cities: Urban Political Ecology and the Politics of Urban Metabolism. London: Routledge.

Taylor, A. F., Kuo, F. E. and Sullivan, W. C. (2001) Coping with ADD: the surprising connection to green play settings. Environment and Behavior, 33: 54-77.

Twiss, J., Dickenson, J. and Duma, S., et al. (2003) Community gardens: lessons learned from California healthy cities and communities. American Journal of Public Health, 93: 1435-1438.

UNDP. (1996) Urban Agriculture: Food, Jobs and Sustainable Cities. New York: United Nations Development Programme.

van Veenhuizen R. (ed.). (2006) Cities Farming for the Future: Urban Agriculture for Green and Productive Cities. Ottawa: IDRC/RUAF.

Viljoen, A. (2005) Continuous Productive Urban Landscapes: Designing Urban Agriculture for Sustainable Cities. Oxford: Elsevier.

Voicu, I. and Been, V. (2008) The effect of community gardens on neighboring property values. Real Estate Economics, 2: 241-283.

Wakefield, S., Yeudall, F. and Taron, C., et al. (2007) Growing urban health: community gardening in SouthEast Toronto. Health Promotion International, 22: 92-101.

Williams, R. (1973) The Country and the City. New York: Oxford University Press.

Wolpe, H. (1972) Capitalism and cheap labour-power in South Africa: from segregation to apartheid. Economy and Society, 1: 425-456.

York, R., Rosa, E. A. and Dietz, T. (2003) A rift in modernity? assessing the anthropogenic sources of global climate change with the STIRPAT model. International Journal of Sociology and Social Policy, 23: 31-51. 